\title{
Az antidepresszívumok és a cukorbetegség közti kapcsolat
}

\author{
Hargittay Csenge, Gonda Xénia, Márkus Bernadett, Vörös Krisztián, TabÁk Gy. Ádám, \\ Kalabay LÁsZló, Rihmer Zoltán, TORZSA Péter
}

A cukorbetegség és a depresszió gyakran komorbid krónikus betegségek. Önmagukban is nagy betegségterhet jelentenek, azonban együttes elófordulásuk tovább növeli a cukorbetegség szövődményeinek számát, a morbiditást és a mortalitást. A két betegség közti kapcsolat kétirányú, amelynek hátterében már ismert és még csak feltételezett mechanizmusok állnak. A szerzók összefoglaló közleményének célja az antidepresszívumok és a cukorbetegség közti kapcsolat bemutatása, illetve a gyógyszerek szénhidrát-anyagcserére gyakorolt hatásának elemzése. Az antidepresszívum-kezelés egyrészt javíthatja a betegek hangulatát, kognitív funkcióit és adherenciáját, amely pozitív hatással lehet a glükózháztartásra, másrészt a gyógyszerek metabolikus mellékhatásai ronthatják is a szénhidrát-anyagcserét. A metabolikus mellékhatások szempontjából a szelektív szerotoninvisszavételgátlók a legelőnyösebbek, a triciklikus antidepresszívumok és a monoaminoxidáz-gátlók szoros kontroll mellett alkalmazhatók. A szerotonin- és noradrenalinvisszavétel-gátlók a noradrenerg aktiválási úton keresztül ronthatják a glykaemiás kontrollt. Az újabb típusú antidepresszívumok hatása pedig pozitív vagy semleges. A depresszió szúrésével és időben elkezdett kezelésével csökkenthetôk a két betegség komorbiditásából származó komplikációk. A cukorbetegek depressziójának kezelése során pedig fontos az antidepresszívumok metabolikus mellékhatásainak a figyelembevétele, és a szénhidrátháztartás szorosabb ellenőrzése.

2-es típusú diabetes mellitus, depresszió, antidepresszívum-kezelés

\section{INTERRELATIONS BETWEEN ANTIDEPRESSANTS AND DIABETES}

Diabetes and depression are frequent comorbidities. They are a heavy burden in themselves, however, as comorbidities increase additionally the number of diabetesrelated complications, morbidity, and mortality. In the background of interrelations, there are both well-known and hypothetical mechanisms. The aim of the present review is to outline these interrelations between antidepressants and diabetes and to discuss the effect of medications on carbohydrate metabolism respectively. Antidepressant treatment on the one hand may improve mood, cognitive function and medication adherence leading to an improved glucose metabolism, on the other hand through their metabolic side effects, they may worsen carbohydrate metabolism. Concerning metabolic side effects, selective serotonin reuptake inhibitors are the safest, while tricyclic antidepressants and monoamine oxidase inhibitors should be administered under close monitoring. Serotonin and noradrenaline reuptake inhibitors may be associated with deteriorating glycaemic control via increased noradrenergic activation. Novel antidepressants, however, have a neutral or positive impact on glycaemic measures. Screening for and temporally adjusted treatment of depression may decrease the risk of comorbidities generated complications. While caring for diabetic patients with depression, one should consider metabolic side effects of antidepressants and close monitoring of carbohydrate metabolism.

type 2 diabetes mellitus, depression, treatment with antidepressants

dr. HARGITTAY Csenge (levelező szerző/correspondent), dr. MÁRKUS Bernadett, dr. VÖRÖS Krisztián, dr. KALABAY László, dr. TORZSA Péter: Semmelweis Egyetem, Általános Orvostudományi Kar, Családorvosi Tanszék/Semmelweis University, Faculty of Medicine, Department of Family Medicine; H-1428 Budapest, Pf. 2. E-mail: hargittay.csenge@med.semmelweis-univ.hu dr. GONDA Xénia, dr. RIHMER Zoltán: Semmelweis Egyetem, Általános Orvostudományi Kar, Pszichiátriai és Pszichoterápiás Klinika/Semmelweis University, Faculty of Medicine, Department of Psychiatry and Psychotherapy, Budapest és Országos Pszichiátriai és Addiktológiai Intézet/National Institute of Psychiatry and Addictions, Budapest

dr. TABÁK Gy. Ádám: Semmelweis Egyetem, Általános Orvostudományi Kar, Belgyógyászati és Onkológiai Klinika/Semmelweis University, Faculty of Medicine, Department of Internal Medicine and Oncology, Budapest

Érkezett: 2020. február 19. Elfogadva: 2020. március 30. 


\section{RÖVIDÍTÉSEK}

BDI: Beck depression inventory (Beck-féle depreszszió-kérdőív)

CES-D: Centre for Epidemiologic Studies-Depression scale (Epidemiológiai kutatási központ depresszióskála)

CI: confidence interval (megbízhatósági tartomány)

D.E.S.I.R.: Data from an Epidemiological Study on the Insulin Resistance Syndrome (Az inzulinrezisztencia-szindrómáról szóló epidemiológiai vizsgálat adatai)

DSM-5: Diagnostic and Statistical Manual of Mental Disorders (Mentális Betegségek Diagnosztikai és Statisztikai Kézikönyve)

EMA: European Medicines Agency (Európai Gyógyszerügynökség)

FDA: Food and Drug Administration (amerikai Élelmiszer- és Gyógyszer-engedélyeztetési Hatóság)

GDS-30: Geriatric Depression Scale (Geriátriai depresszióskála)

HAM-D: Hamilton Depression Rating Scale (Hamilton-depresszióskála)

HADS: Hospital Anxiety and Depression Scale (Kórházi szorongás- és depresszióskála)

$\mathrm{HbA}_{1 \mathrm{c}}$ : hemoglobin $\mathrm{A}_{1 \mathrm{c}}$

HOMA-B: Homeostasis Model Assessment - Beta cell function (a $\beta$-sejt-múködés jellemzésére használt matematikai modell)

HOMA-S: Homeostasis Model Assessment - insulin sensitivity (az inzulinhatás jellemzésére alkalmazott matematikai modell)
IDF: International Diabetes Federation (Nemzetközi Diabetes Szövetség)

ICD10: International Statistical Classification of Diseases and Related Health Problems (Betegségek Nemzetközi Osztályozása-10, BNO-10)

MAO: monoamine oxidase inhibitor (monoaminoxidáz-gátló)

MINI: Mini International Neuropsychiatric Interview (Mini nemzetközi neuropszichiátriai interjú)

NDRI: norepinephrine-dopamine reuptake inhibitor (noradrenalin- és dopaminvisszavétel-gátló)

NHANES: National Health and Nutrition Examination Survey (Nemzeti Egészség és Táplálkozási Állapotfelmérés)

OGTT: oral glucose tolerance test (orális glükóztolerancia-teszt)

OR: odds ratio (esélyhányados)

PHQ-9: Patient Health Questionnaire („Betegek Egészségi Állapota” kérdőív)

RR: relative risk (relatív rizikó)

SSRI: selective serotonin reuptake inhibitor (szelektív szerotoninvisszavétel-gátló)

TCA: tricyclic antidepressant (triciklusos antidepresszívum)

TeCA: tetracyclic antidepressant (tetraciklikus antidepresszívum)

WHO: World Health Organization (Egészségügyi Világszervezet)

WHS: World Health Survey (Világ Egészség Felmérés)
A cukorbetegség egyre több embert érint a világon, és gyakran már csak a szövődmények kialakulásakor fedezik fel. Gyakorisága és szövődményei révén óriási betegségterhet jelent. A Nemzetközi Diabetes Szövetség (International Diabetes Federation, IDF) legfrissebb becslése szerint a világon jelenleg 463 millió diabeteses beteg él, számuk folyamatosan emelkedik, 2045-re elóreláthatóan 700 millióra növekszik. Szintén az IDF legfrissebb becslése szerint hazánkban a cukorbetegség prevalenciája a 20-79 év közötti korosztályban 9,3\% volt 2019-ben (1). Hazai adatok alapján a prevalencia 2016-ban a teljes lakosságra vonatkoztatva $7,27 \%$ volt (férfiak: 6,93\%, nók: 7,59\%). Az életkor előrehaladtával nőtt az elófordulási gyakoriság, a 65-84 év közötti korosztályban 20-25\% volt, a 75-79 év közöttieknél volt a legmagasabb, $25 \%$ (2).

A cukorbetegséghez hasonlóan a depresszió is gyakori megbetegedés. Az Egészségügyi Világszervezet (World Health Organization, WHO) becslése szerint 322 millió embert érint a világon és a munkaképesség-csökkenés vezetô oka (3). Nemzetközi adatokhoz hasonlóan, reprezentatív mintán történt hazai felmérések szerint, az orvosi értelemben vett és nemzetközi standard DSM5/BNO-10 (Diagnostic and Statistical Manual of Mental Disorders-5, Mentális Betegségek Diagnosztikai és Statisztikai Kézikönyve-5/Betegségek Nemzetközi Osztályozása-10) kritériumoknak megfelelő (unipoláris) major depresszió élettartam 1 éves és 1 hónapos prevalenciája a felnőtt lakosság körében $15,1 \%$, 7,1\% és 2,6\% volt; nőknél pedig kétszer gyakoribb (4). Az alapellátásban, 2006-ban történt felmérés eredményei szerint, a DSM-IV-ben szenvedő depressziós kórképek pontprevalenciája 18,5\%, a major depressziós epizódé $7,3 \%$ volt $(5)$.

$\mathrm{Az}$ Egészségügyi Világszervezet által végzett Világ Egészség Felmérés, a World Health Survey (WHS) eredményei alapján a depresszió okozza a legnagyobb egészségkárosodást, megelőzve más krónikus betegségeket (például asthma, arthritis, diabetes). Amennyiben a depresszióhoz más krónikus betegség is társul, akkor nagyobb az egészségkárosodás mértéke ahhoz képest, amikor a depresszió vagy a krónikus betegség önmagában van jelen, vagy több krónikus beteg- 
ség együtt. Moussavi és munkatársainak vizsgálata szerint depresszió esetén volt a legalacsonyabb, 72,9 pont az átlagos egészségpontszám (health score), míg angina esetén 79,6 , arthritis esetén 79,3, diabetes esetén pedig 78,9 pont. Depresszióhoz társuló egyéb társbetegségek esetén tovább csökkent a betegek egészségpontszáma. A legalacsonyabb, 58,5 pont a cukorbetegség és depresszió együttes előfordulásakor volt. Ez az alacsony pontszám közel azonos volt azoknak a betegeknek a pontszámával, akiknek a depreszszió mellett kettő vagy több társbetegsége volt jelen (56,1 pont) (6).

A depresszió és a diabetes szoros kapcsolatára a hazai szerzők már több mint 35 éve felhívták a figyelmet (7). A depresszió gyakran fordul elő cukorbetegek körében, ezzel kapcsolatban számos tanulmány született (8-12). Egy 2019-ben megjelent, 248 vizsgálatot feldolgozó (83020 812 résztvevő) szisztematikus összefoglaló és metaanalízis eredményei alapján a világon a depreszszió előfordulási gyakorisága 2-es típusú cukorbetegek körében $28 \%$ volt. Európában és Afrikában alacsonyabb, $24 \%$ és $27 \%$, Ausztráliában és Ázsiában pedig magasabb, 29 és 32\% volt az előfordulási gyakoriság. Amerikában a prevalencia szintén $28 \%$ volt (13).

A cukorbetegek körében elóforduló depreszszió prevalenciájával kapcsolatos becsléseket számos tényezó befolyásolja: a vizsgálatba bevont betegek életkora, a nemek aránya, a vizsgálat jellege (keresztmetszeti, hosszmetszeti), a cukorbetegség fennállásának ideje, a diabetes és a depresszió diagnosztizálásának módja, illetve kritériumai, valamint a cukorbetegséggel együtt előforduló komorbid betegségek és a diabetes szövődményeinek jelenléte. Az 1. táblázatban az Európa néhány országában a 2-es típusú cukorbetegek körében végzett tanulmányok demográfiai adatai és a körükben előforduló depresszió prevalenciája látható. Fontos annak megemlítése, hogy az orvosi értelemben vett depresszió előfordulásának detektálása csak az ICD-10 (International Statistical Classification of Diseases and Related Health Problems, Betegségek Nemzetközi Osztályozása-10) vagy MINI módszerrel (Mini International Neuropsychiatric Interview, Mini Nemzetközi Neuropszichiátriai Interjú) végzett vizsgálatokban történt, a többi tanulmány a depressziós tünetek kérdőívvel történő felmérésérôl szól, de ismert, hogy az így kapott eredmények a definitív, depressziós betegségben szenvedőknél nagyobb gyakoriságot mutatnak.

A cukorbetegség és a depresszió komorbiditása jól ismert (7-13). A cukorbetegségnek és depresszív állapotoknak önmagukban és következ- ményeikkel együttvéve is nagy a népegészségügyi jelentôségük. Együttes elófordulásuk esetén még tovább nő a morbiditás és a mortalitás. A depresszió súlyossága negatívan hat a diabeteses betegek kezelésben való együttmúködésére, a javasolt diéta betartására, a szükséges fizikai aktivitásra és mentális státuszra, növekszik az egészségre káros magatartásformák száma, és magasabb az ellátás költsége (27).

Kétirányú kapcsolatról van szó, a cukorbetegség növeli a depresszió kialakulásának kockázatát és fordítva, a depresszió növeli a cukorbetegség kialakulásá-

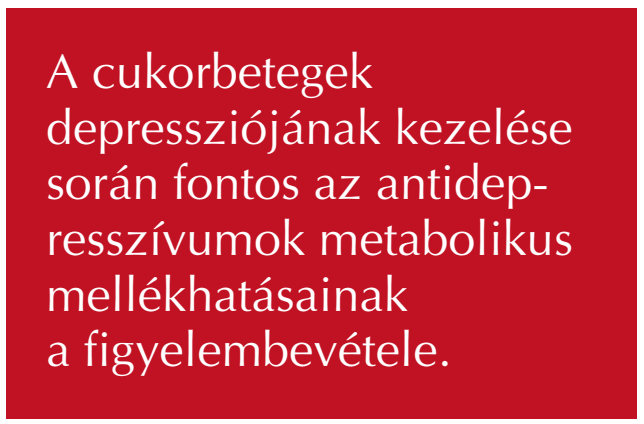
nak az esélyét. A két betegség közti kapcsolat hátterében már ismert és még csak feltételezett mechanizmusok állnak. Ezek közé tartoznak a közös patogenetikai/ etiológiai tényezők, mint például a közösen öröklött hajlam, a környezeti, társadalmi-gazdasági és életmódi tényezők, a stresszrendszer aktiválódása, az immunrendszer múködési zavara, a gyulladásos paraméterek emelkedett szintje és az inzulinszerú növekedési faktor-I eltérései, illetve a depresszió és a diabetes direkt oki kapcsolatban állhat a másik betegséggel (28). További befolyásoló tényező lehet, amely növeli a cukorbetegség kialakulásának kockázatát, az antidepresszív kezelés és a sokszor ezzel kapcsolatos elhízás is (29). Jelen közleményünkben az antidepresszívumok szénhidrátháztartásra gyakorolt hatását és az antidepresszívumkezelés és a cukorbetegség közti kapcsolatot mutatjuk be.

\section{A különböző antidepresszívumok metabolikus hatásai}

Az antidepresszívumok a leggyakrabban felírt gyógyszerek közé tartoznak az Egyesült Királyságban és Amerikában $(30,31)$. Az Egyesült Királyságban 2015-höz képest 6\%-kal több antidepresszívumot írtak fel 2016-ban, összesen 64,7 millió receptírást regisztráltak (30).

Az antidepresszív kezelés hatására javulhat a betegek depresszív hangulata, a diéta követése és a gyógyszerszedési adherencia is, melyek jobb szénhidrát-anyagcseréhez vezetnek. Az antidepresszívumok egy része azonban nem anyagcseresemleges. Különbözô metabolikus mellékhatásokon keresztül a gyógyszerek ronthatják a szénhidrátháztartást, amely odafigyelést igényel a kezelőorvos részéről. 
1. táblázat. Demográfiai adatok és a depresszió prevalenciája 2-es típusú cukorbetegek között Európa nébány országában

\begin{tabular}{|c|c|c|c|c|c|}
\hline Vizsgálat & Vizsgálat típusa & Betegszám & $\begin{array}{l}\text { Depresszió } \\
\text { diagnózisa }\end{array}$ & $\begin{array}{l}\text { Átlagéletkor, } \\
\text { nemek aránya }\end{array}$ & $\begin{array}{l}\text { Depresszió } \\
\text { prevalenciája }\end{array}$ \\
\hline $\begin{array}{l}\text { Degmecić D, et al., } 2014 \\
\text { (Horvátország) (14) }\end{array}$ & Keresztmetszeti & $\begin{array}{l}\text { 108, ebból } \\
66 \text { DMT2 }\end{array}$ & HAM-D & 61,11 (44-78) év; 42\% nő & $78,7 \%$ \\
\hline $\begin{array}{l}\text { Foran E, et al. } 2015 \\
\text { (Írország) (15) }\end{array}$ & Keresztmetszeti & 283 & HADS & 68 (50-98) év; 42\% nó & $22 \%$ \\
\hline $\begin{array}{l}\text { Gorska-Ciebiada M, et al., } \\
2014 \text { (Lengyelország) (16) }\end{array}$ & Keresztmetszeti & 276 & GDS-30 & 73,6 \pm 4,8 év; 54\% nő & $29,7 \%$ \\
\hline $\begin{array}{l}\text { Indelicato L, et al., } 2017 \\
\text { (Olaszország) (17) }\end{array}$ & Keresztmetszeti & 172 & BDI-II & $64,0(58,0-69,0)$ év; 40\% nő & $18,6 \%$ \\
\hline $\begin{array}{l}\text { Jacob L, et al., } 2016 \\
\text { (Németország) (18) }\end{array}$ & $\begin{array}{l}\text { Hosszmetszeti } \\
(2004-2013)\end{array}$ & 90,412 & ICD10 & 65,5 év (SD: 11,7); 49,8\% nő & $\begin{array}{l}5,9 \% \text { - } 1 \text { évvel; } \\
\text { 17,7\% - } 5 \text { évvel; } \\
\text { 30,3\% - } 10 \text { évvel } \\
\text { a diabetes diagnózisa } \\
\text { után }\end{array}$ \\
\hline $\begin{array}{l}\text { Majdan M, et al., } 2012 \\
\text { (Szlovákia) (19) }\end{array}$ & Keresztmetszeti & 1043 & PHQ-9 & 65 (57-62) év; 60\% nó & $53 \%$ \\
\hline $\begin{array}{l}\text { Mikaliūkštienė A, et al., } \\
2014 \text { (Litvánia) (20) }\end{array}$ & Keresztmetszeti & 1022 & HADS & 59,3 év; $63,6 \%$ nő & $28,5 \%$ \\
\hline $\begin{array}{l}\text { Mocan AŞ, et al., } 2016 \\
\text { (Románia) (21) }\end{array}$ & Keresztmetszeti & 354 & BDI-II & $61,14 \pm 8,5$ év; $58,5 \%$ nő & $16,9 \%$ \\
\hline $\begin{array}{l}\text { Nefs G, et al., } 2019 \\
\text { (Hollandia és Ausztrália) (22) }\end{array}$ & Keresztmetszeti & 3808 & PHQ-9 & $60 \pm 10$ év; $49 \%$ nó & $11 \%$ \\
\hline $\begin{array}{l}\text { Nowakowska M, et al., } 2019 . \\
\text { (Egyesült Királyság) (23) }\end{array}$ & $\begin{array}{l}\text { Hosszmetszeti } \\
(2007-2017)\end{array}$ & 102,394 & $\begin{array}{l}\text { Elektronikus, } \\
\text { egészségügyi } \\
\text { adatok az alap- } \\
\text { ellátás adatbázisából }\end{array}$ & $62,1 \pm 13,1$ év; 43,7\% nó & $\begin{array}{l}\text { Gazdagabb } \\
\text { területeken: } 14,9 \% \\
\text { Szegényebb } \\
\text { területeken: } 14,1 \%\end{array}$ \\
\hline $\begin{array}{l}\text { Pouwer F, et al., } 2010 \\
\text { (Hollandia) (24) }\end{array}$ & Keresztmetszeti & $\begin{array}{l}722 \text { T1DM } \\
\text { és T2DM }\end{array}$ & CES-D & T2DM: $61 \pm 12$ év & $\begin{array}{l}\text { T2DM: CESD: } \\
35 \% \text { férfi, } 38 \% \text { nô }\end{array}$ \\
\hline $\begin{array}{l}\text { Salinero-Fort MA, et al., } 2018 \\
\text { (Spanyolország) (25) }\end{array}$ & $\begin{array}{l}\text { Hosszmetszeti } \\
(2007-2011)\end{array}$ & 2955 & MINI & 70,2 (SD 10,6) év; 48,1\% nó & $20 \%$ \\
\hline $\begin{array}{l}\text { Sotiropoulos A, et al., } 2008 \\
\text { (Görögország) (26) }\end{array}$ & Keresztmetszeti & 320 & BDI & $\begin{array}{l}\text { férfi: } 62,8 \pm 6,8 \text { év } \\
\text { nó: } 63,6 \pm 7,6 \text { év; } 58,1 \% \text { nó }\end{array}$ & $33,4 \%$ \\
\hline
\end{tabular}

Az alapellátásban leggyakrabban alkalmazott antidepresszívumok a szelektív szerotoninviszszavétel-gátlók (selective serotonin reuptake inhibitor, SSRI: fluoxetin, fluvoxamin, paroxetin, sertralin, citalopram, escitalopram), amelyek előnyösebb mellékhatásprofillal rendelkeznek, mint a triciklusos és tetraciklikus antidepresszívumok (tricyclic and tetracyclic antidepressant, TCA, TeCA). Nincs antikolinerg, antihisztaminerg és antiadrenerg hatásuk. Az SSRI-szerek a többi antidepresszívum-készítményhez képest kevésbé okoznak súlygyarapodást, kivéve a paroxetin (32). A diabetes és a depresszió egyaránt negatívan befolyásolhatja a szexuális funkciót. Az SSRI-készítmények egyik gyakori mellékhatása a szexuális diszfunkció, ezért ez a lehetséges mellékhatás a készítmény szedésekor diabeteses betegekben fokozottabban jelentkezhet.

A sertralin testsúlyra, derékkörfogatra és a glykaemiás kontrollra kifejtett hatását vizsgálták egy kis létszámú ( $\mathrm{n}=33$ ), prospektív tanulmányban, depressziós, 2-es típusú cukorbetegek körében. 12 hét elteltével a kontrollvizsgálaton szignifikáns csökkenést tapasztaltak a testsúlyban $(-2 \mathrm{~kg} ; \mathrm{p}<0,001)$, a testtömegindexben $\left(30,41 \mathrm{~kg} / \mathrm{m}^{2}\right.$-ról 29,6 kg/m²-re; $\left.\mathrm{p}<0,001\right)$ és a derékkörfogatban $(-7 \mathrm{~cm} ; \mathrm{p}<0,001)$ a kiindulási értékhez képest. Az éhomi, postpandrialis és a hemoglobin $\mathrm{A}_{1 \mathrm{c}}{ }^{-}\left(\mathrm{HbA}_{1 \mathrm{c}}{ }^{-}\right)$értékben tapasztalt csökkenés ugyanakkor nem bizonyult szignifikánsnak (33).

Egy korábbi vizsgálatban Lustman és munkatársai szignifikáns csökkenést figyeltek meg az átlag$\mathrm{HbA}_{1 \mathrm{c}}$-értékben $(-0,4 \% \pm 1,4 \% ; \mathrm{p}=0,002) 16$ héttel a sertralinkezelés megkezdése után (34).

A fluoxetin csökkenti a hyperglykaemiát, normalizálja a glükózháztartást, és növeli az inzulinérzékenységet (35). Egy metaanalízis a fluoxetin metabolikus hatásait vizsgálta 2-es típusú cukorbetegekben. Eredményeik alapján a 6-12 hóna- 
pos fluoxetinkezelés testsúlycsökkenést okoz $[-4,27 \mathrm{~kg}, 95 \%$ CI (confidence interval, megbízhatósági tartomány): 2,58-5,97; $\mathrm{p}<0,001]$, javítja az éhomi vércukor- $(-1,41 \mathrm{mmol} / 1 ; 95 \% \mathrm{CI}$ : $0,19-2,64 ; \mathrm{p}=0,02)$, illetve a trigliceridértéket $(-0,54 \mathrm{mmol} / \mathrm{l} ; 95 \%$ CI: 0,35-0,73; p < 0,001) a placebocsoporthoz képest. A $\mathrm{HbA}_{1 \mathrm{c}}$-értékben mért 0,78\%-os (95\% CI: 0,23-1,78) csökkenés nem volt szignifikáns $(\mathrm{p}=0,13)(36)$.

A triciklusos és tetraciklikus antidepresszívumok (TCA, TeCA) (imipramin, amitriptylin, clomipramin, dibenzepin, maprotilin, mianserin) nem szelektív szerotonin- és/vagy noradrenalin-visszavételt gátlók. Antihisztaminerg hatásuk következményeként testsúlynövekedést okoznak (37). Antikolinerg mellékhatásaik a hyperglykaemia tüneteit utánozhatják (szájszárazság, látászavar), antiadrenerg hatásuk miatt pedig gyakori az ortosztatikus hypotonia. A hasnyálmirigy $\beta$-sejtjein található muszkarin M3-receptorok blokkolásán keresztül pedig gátolják az inzulinszekréciót, ezáltal növelik a vércukorszintet (38). Ezen mellékhatásaik miatt csak szoros kontroll mellett alkalmazhatók cukorbetegeknél.

A monoaminoxidáz-gátlók (monoamine oxidase inhibitor, MAO nialamid, phenelzin, tranylcypromin, moclobemid, selegilin), fóleg az irreverzibilis MAO-k (a moclobemid kivételével az összes) esetében növekedhet a testsúly, ami a cukorbetegség szempontjából hátrányos hatás és emellett hypoglykaemiát is okozhatnak $(35,39)$.

A triciklusos antidepresszívumoknál tapasztalt kedvezőtlen mellékhatások nem jelentkeznek a kettôs hatású antidepresszívumok (venlafaxin, duloxetin) esetében, amelyek gátolják a szerotonin és a noradrenalin visszavételét. Alkalmazásuk biztonságos, de cukorbetegség szempontjából a noradrenerg aktiválási úton keresztül ronthatják a glykaemiás kontrollt (40). A duloxetin jól alkalmazható a neuropathiás fájdalom kezelésében (41). Egy tanulmányban, mely három randomizált klinikai vizsgálat adatait dolgozta fel, a metabolikus paraméterekben bekövetkezô változásokat követték duloxetinkezelésben részesülő, bilaterális diabeteses perifériás neuropathiában szenvedő 1-es és 2-es típusú cukorbetegeknél $(\mathrm{n}=1024)$. Mérsékelt emelkedés volt észlelhetô az éhomi vércukorértékben a rövid (12 hét) és a hosszú távú (további 52 hét) duloxetinkezelés alkalmazása mellett (0,50 és $0,67 \mathrm{mmol} / \mathrm{l}, \mathrm{p}=0,002)$. A HbA 1 -értékben mérsékelt emelkedést tapasztaltak a hosszú távú kezelés során a duloxetinnel kezelt és a kontrollcsoportban is, de ez a változás statisztikailag nagyobb volt a duloxetint szedó csoportban $(0,52 \%$ vs. $0,19 \% ; \mathrm{p}<0,001)(42)$.
Az újabb antidepresszívumok közé tartozó, szintén kettôs hatású mirtazapin testsúlygyarapodást okozhat (43). Egy 2014-ben megjelent vizsgálat alapján a mirtazapin szignifikánsan növelte a testtömegindexet a gyógyszerrel kezelt cukorbetegeknél $\left(1,0 \pm 0,6 \mathrm{~kg} / \mathrm{m}^{2}\right)$ a kontrollcsoporthoz képest $\left(0,3 \pm 0,4 \mathrm{~kg} / \mathrm{m}^{2} ; \mathrm{p}<0,001\right)$. Más paraméterek, mint a $\mathrm{HbA}_{1 \mathrm{c}}$, a vércukor- és a lipidértékek nem rosszabbodtak az alkalmazott hat hónapos kezelés alatt, tehát a rövid távú mirtazapinnal történő kezelés biztonságosnak bizonyult a stabil állapotú cukorbetegeknél (44).

A noradrenalin- és dopaminvisszavételt gátló (norepinephrine-dopamine reuptake inhibitor, NDRI) bupropion jól tolerálható, nem befolyásolja a szexuális funkciót, és nem okoz testsúlynövekedést, inkább testsúlycsökkenéshez vezet (43). Az amerikai Élelmiszer- és Gyógyszerengedélyeztetési Hatóság (FDA, Food and Drug Administration) és az Európai Gyógyszerügynökség (EMA, European Medicines Agency) jóváhagyásával fogyasztószerként is alkalmazzák a naltrexonnal fix kombinációban $(45,46)$. Egy 2011-ben, bupropionkezelésben részesült major depressziós cukorbetegek körében végzett vizsgálatban szignifikáns javulást írtak le a betegek hangulatában, a glykaemiás kontrollban és a szexuális funkcióban (47). Lustman és munkatársai nyílt vizsgálatban $(\mathrm{n}=93)$ arra keresték a választ, hogy a 2-es típusú cukorbetegségben szenvedő major depressziós betegek bupropionnal történő rövidebb, 10 hetes, illetve hosszabb, 24 hetes kezelése javítja-e a $\mathrm{HbA}_{1 c}$-értéket, és a változások kapcsolatban állnak-e a hangulat változásában, a cukorbetegek öngondoskodásában, vagy az antropometriai adatokban bekövetkező változásokkal. Eredményeik alapján a $\mathrm{HbA}_{1 \mathrm{c}}$-szint szignifikánsan csökkent $(-0,5 \pm 1,0 \%$; $p<$ $0,001)$ a 10 hetes kezelés során. Ezen belül szignifikáns csökkenés volt megfigyelhető azoknál, akik remisszióba kerültek $(-0,6 \pm$ $1,1 \%$; $<<0,001)$, ugyanak-

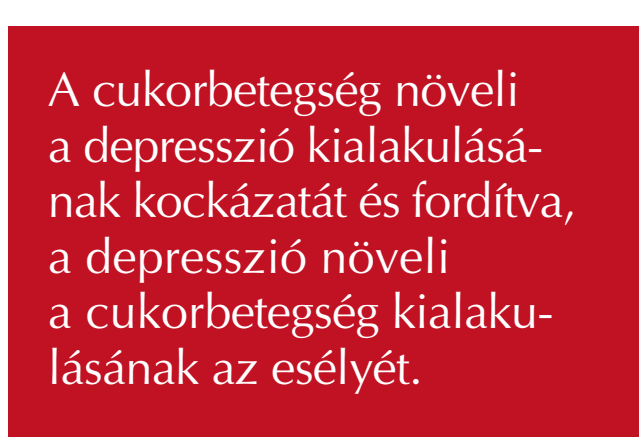
kor az eltérés nem volt szignifikáns $(-0,1 \pm 0,7 \% ; \mathrm{p}=0,7)$ azoknál, akik nem kerültek remisszióba. A $\mathrm{HbA}_{1 \mathrm{c}}$ alacsonyabban maradt a kiinduló értékhez képest a tünetmentes fenntartó időszak alatt $(-0,7 \pm 1,3 \%$; $p<$ $0,001)$. A hangulatban és testösszetételben történt változás összefüggésben állt a glykaemiás kontroll rövid távú javulásával. A fenntartó kezelés során észlelt $\mathrm{HbA}_{1 \mathrm{c}}$-érték javulása pedig a hangulat javulásával állt összefüggésben, és független volt a testsúlytól és az öngondoskodástól. Tehát a 
depresszió javulásának kedvező hatása volt a glykaemiás kontrollra, függetlenül a testsúlytól (48).

A fenti vizsgálatok alapján elmondhatjuk, hogy a cukorbetegek depressziójának kezelésében alkalmazott antidepresszívumok közül a kedvezôbb mellékhatásprofil miatt a szelektív szerotoninvisszavétel-gátlók előnyösebbnek tûnnek a triciklusos antidepresszívu-

Az irodalmi adatok alapján összefüggés van az antidepresszívumok használata és a diabetes kialakulása között. mokkal szemben. A triciklikus antidepresszívumok korlátozottan használhatók cukorbetegeknél vércukorszintet növelő hatásuk miatt, alkalmazásukkor a vércukorszint szorosabb kontrollja szükséges. A monoaminoxidáz-gátlók szintén korlátozottan alkalmazhatóak a testsúlynövekedés és a hypoglykaemia veszélye miatt. A kettős hatású készítményeknél figyelembe kell venni, hogy a noradrenerg aktiválási úton keresztül ronthatják a szénhidrátháztartást. Az újabb típusú antidepresszívumoknak (mirtazapin, bupropion) pedig semleges vagy pozitív hatásuk van a glykaemiás kontrollra, különösen a rövid távú kezelések esetében.

\section{Az antidepresszívumok hatása a diabetes kialakulására és a szénhidrát-anyagcserére}

Az antidepresszívumok cukorbetegség kialakulásában játszott szerepével kapcsolatban számos vizsgálat született eltérő eredményekkel, és a háttérben álló okok még nem teljesen tisztázottak. Egyes vizsgálatok úgy vélik, hogy nincs összefüggés az antidepresszívumok és a cukorbetegség kialakulása között, más tanulmányok szerint az antidepresszívumok növelik a cukorbetegség kialakulásának kockázatát, de van olyan vizsgálat is, amely arra a következtetésre jutott, hogy az antidepresszívumok használata depreszsziós, 2-es típusú cukorbetegek körében javítja a szénhidrát-anyagcserét. Az ellentmondásos eredmények oka elsősorban az lehet, hogy - mint az alábbiakban részletesen kifejtjük - a különböző biokémiai hatásmechanizmusú készítmények eltérô módon befolyásolhatják a szénhidrátanyagcserét.

A Nemzeti Egészség és Táplálkozási Állapotfelmérés (NHANES, National Health and Nutrition Examination Survey) adatait feldolgozó keresztmetszeti vizsgálat nem talált összefüggést az antidepresszívum-használat és az emelkedett éhomi vércukor-, $\mathrm{HbA}_{1 c}$ - és 2 órás OGTT- (oral glucose tolerance test, orális glükóztolerancia-teszt) szintek vagy a csökkent inzulinérzékenység között nem cukorbetegek körében (49). Hasonló eredményeket kaptak Kammer és munkatársai szintén a NHANES adatait feldolgozva. A legtöbb antidepresszívumnál nem találtak szignifikáns összefüggést az emelkedett $\mathrm{HbA}_{1 \mathrm{c}}{ }^{-}$ értékkel, kivéve a selegilin esetében. Azoknak a nem cukorbetegeknek, akik selegilint szedtek, magasabb volt a $\mathrm{HbA}_{1 c}$-értékük az antidepresszívumot nem szedőkhöz képest (50).

Egy másik vizsgálatukban különböző etnikumú, alacsony jövedelmú diabeteses $(\mathrm{n}=462)$ és nem diabeteses $(n=1983)$ betegek körében vizsgálták az antidepresszívumok szedése és a $\mathrm{HbA}_{1 c}$-szint közti kapcsolatot. Szignifikáns összefüggést találtak az egyszerre több különbözô típusú antidepresszívumot szedők alcsoportja és az emelkedett $\mathrm{HbA}_{1 c}$-érték között cukorbetegek körében (hatásnagyság: 0,12; $\mathrm{p}=0,04$ ). Nem találtak összefüggést az antidepresszívum-szedés és a $\mathrm{HbA}_{1 \mathrm{c}}$-szint között a nem cukorbeteg csoportban. Továbbá nem találtak kapcsolatot a $\mathrm{HbA}_{1 c}$-érték és az antidepresszívum-szedés között azon cukorbetegek körében, akik egyféle antidepresszívumot szedtek (51).

Egyes vizsgálatok arra hívták fel a figyelmet, hogy az antidepresszívumok szénhidrát-anyagcserére gyakorolt hatása függhet a gyógyszer típusától. Deuschle és munkatársai összefoglaló közleményükben arra a megállapításra jutottak, hogy a depresszióban szenvedő nem cukorbetegek szénhidrátháztartása javult SSRI-kezelés hatására, a TCA-t szedő cukorbetegeké pedig romlott, illetve az SSRI szedése a nem cukorbetegek körében csökkentette a diabetes kialakulásának rizikóját (52). Yoon és munkatársai metaanalízisükben arra a következtetésre jutottak, hogy az antidepresszívumok használata szignifikánsan növeli a cukorbetegség előfordulási gyakoriságát (RR (relative risk, relatív rizikó): 1,49; 95\% CI: 1,29-1,71). Alcsoport-analízis alapján a cukorbetegség kialakulásának rizikója nőtt mind az SSRI-t (RR: 1,35; 95\% CI: 1,15-1,58) használók, mind a TCA-t (RR: 1,57; 95\% CI: 1,26-1,96) szedők körében (53). Egy nemrég megjelent szisztematikus összefoglaló és metaanalízisben is hasonló eredményeket kaptak. Összefüggést találtak az antidepresszívumok használata és az újonnan felismert cukorbetegség között (RR: 1,27 95\% CI: $1,19-1,35 ; \mathrm{p}<0,001)(54)$.

Fontos megemlíteni, hogy az antidepresszívumok és a diabetes közti kapcsolat vizsgálatát nehezíti, hogy további tényezók is szerepet játszhatnak ebben a folyamatban. Befolyásoló tényező a depresszió súlyossága, az antidepreszszívum-kezelés hossza, és a gyógyszer dózisa. 
Ezek önmagukban is a 2-es típusú diabetes kialakulásának fokozott kockázatával járnak. Andersobn és munkatársai tanulmányukban arra a következtetésre jutottak, hogy azon depressziós betegek körében, akik több mint 2 évig szedtek antidepresszívumot közepes vagy magas napi dózisban, a cukorbetegség kialakulásának kockázata közel kétszer nagyobb volt a gyógyszert nem szedő depressziós betegekhez képest (incidenciaarányszám-hányados $=1,84 ; 95 \%$ CI: 1,35-2,52). Ez az összefüggés mind a triciklikus antidepresszívumot, mind a SSRI-t szedőknél megfigyelhetô volt (55). Kivimäki és munkatársai populációs alapú vizsgálatának eredményei alapján az antidepresszívumok (SSRI, TCA) kumulatív dózisa pozitív összefüggést mutatott a későbbi cukorbetegség kockázatával és a testsúlygyarapodás mértékével (56).

Egy további longitudinális (18 év) vizsgálatuk eredményei alapján az orvos által diagnosztizált cukorbetegség előfordulása gyakoribb volt az antidepresszívumot szedők között a nem szedôkhöz képest [OR (odds ratio, esélyhányados): 3,10; 95\% CI: 1,66-5,78]. Nem találtak összefüggést az antidepresszívum-használat és a nem diagnosztizált diabetes, illetve a magasabb éhomi, illetve OGTT során mért 2 órás értékek és az emelkedett vércukorszintek között. Ez a vizsgálat felhívja a figyelmet arra, hogy az antidepresszívum felírása miatti gyakoribb orvosbeteg találkozások következtében hamarabb és könnyebben fény derülhet a cukorbetegségre (szúrési torzítás) (57). Eredményeiket megerôsítette egy 9 évig tartó hosszmetszeti tanulmány $(n=4700)$, amely egy francia inzulinrezisztencia-szindrómáról szóló epidemiológiai vizsgálat, a D.E.S.I.R. (Data from an Epidemiological Study on the Insulin Resistance Syndrome) adatait dolgozta fel, és az inzulinérzékenységet is vizsgálta nem cukorbetegek körében. Nem találtak szignifikáns összefüggést az antidepresszívum-használat és az éhomi vércukorszint, a $\mathrm{HbA}_{1 \mathrm{c}}$-érték, a HOMA-B és HOMA-S index értékének változása között (58).

Brieler és munkatársai retrospektív kohorsz tanulmányukban (n = 1399) arra a következtetésre jutottak, hogy az antidepresszívumok használata (a gyógyszerfelírást vizsgálva) depressziós, 2-es típusú cukorbetegek körében javítja a szénhidrát-anyagcserét. Azoknak a betegeknek, akik antidepresszívumot szedtek, kétszer nagyobb volt az esélyük arra, hogy elérjék a glykaemiás kontrollt azokhoz viszonyítva, akik nem kaptak antidepresszívumot (OR: 1,95; 95\% CI: 1,023,71). Vizsgálatuk felveti, hogy a szénhidrátháztartásban fellépó javulás hátterében egyrészt az antidepresszívum-kezelés hatása, másrészt a betegek hangulatában bekövetkező javulás állhat, illetve mindkettő (59).

A szakirodalmat áttekintve láthatjuk, hogy nagyon összetettek és idônként eltérőek a vizsgálati eredmények. Ezek legfontosabb okai a depresszió diagnózisának metodikai, illetve az antidepresszívumok hatásmechanizmusának biokémiai heterogenitásában rejlik. Az antidepreszszívumok szénhidrátháztartásra gyakorolt hatását számos tényezó befolyásolhatja, amelyek tisztázásához további vizsgálatokra van szükség.

\section{Következtetések}

A depresszió elófordulása diabeteses betegek között gyakori. Sok beteg esetében nem ismerik fel és nem kezdődik meg időben a kezelés, ami ronthatja a cukorbetegek terápiával való együttmúködését, szénhidrátháztartását, nőhet a betegek morbiditása és mortalitása. Mindezért fontos a cukorbetegek szúrése depresszió irányába, illetve a depresszió diagnózisa esetén a kezelés mielőbbi megkezdése, amelynek hatására javulhat a betegek adherenciája és szénhidrátháztartása, ami alapvetô a cukorbetegség szövődményeinek megelôzése szempontjából. Irodalmi adatok alapján van összefüggés az antidepresszívumok használata és a diabetes kialakulása között és a gyógyszerek nem egyformán befolyásolják a diabetesben szenvedők anyagcsere-állapotát. A cukorbetegek depressziójának kezelése során elsősorban olyan készítményeket válasszunk, amelyek előnyösek a szénhidrátháztartásra. Az anyagcserére negatívan ható antidepresszívumok használata esetén javasolt a cukorbetegek gyakoribb ellenôrzése, a diéta szorosabb kontrollja, hogy időben felismerhetô legyen a lehetséges metabolikus mellékhatások megjelenése.

\section{Irodalom}

1. International Diabetes Federation. IDF Diabetes Atlas. Ninth edition 2019. Available from: http://www.diabetesatlas.org (Letöltés ideje: 2020.01.11.)

2. Jermendy Gy, Kiss Z, Rokszin Gy, Abonyi-Tóth Zs, Wittmann I, Kempler P. Antidiabetikummal kezelt 2-es típusú cukorbe- tegek epidemiológiai adatai Magyarországon 2016-ban központi regiszter adatbázisának elemzése. Diabet Hung 2019;27:205-11. https://doi.org/10.24121/dh.2019.15

3. World Health Organization. Depression and Other Common Mental Disorders. Global Health Estimates. Available 
from: http://www.who.int/mental_health/management/ depression/prevalence_global_health_estimates/en/ (Letöltés ideje: 2019.12.10.)

4. Szádóczky E, Papp Zs, Vitrai J, Rihmer Z, Füredi J. The prevalence of major depressive and bipolar disorders in Hungary: Results from a national epidemiologic survey. $J$ Affect Disord 1998;50:153-62. https://doi.org/10.1016/S0165-0327(98)00056-1

5. Rihmer Z, Gonda X, Eóry A, Kalabay L, Torzsa P. A depresszió szúrése az alapellátásban Magyarországon és ennek jelentősége az öngyilkosság megelőzésében. Psychiatr Hung 2012;27:224-32. Available from: https://lib.semmelweis.hu/sepub/pdf/2012/a547 (Letöltés ideje: 2019.12.10).

6. Moussavi S, Chatterji S, Verdes E, Tandon A, Patel V, Ustun $B$. Depression, chronic diseases, and decrements in health: results from the World Health Surveys. Lancet 2007; 370:851-8. https://doi.org/10.1016/S0140-6736(07)61415-9

7. Rihmer Z, Arató M. Depression and diabetes mellitus. A study of the relationship between serum cortisol and blood sugar levels in patients with endogenous depression. Neuropsychobiology 1982;8:315-8. https://doi.org/10.1159/000117918

8. Anderson RJ, Freedland KE, Clouse RE, Lustman PJ. The prevalence of comorbid depression in adults with diabetes: a meta-analysis. Diabetes Care 2001;24:1069-78. https://doi.org/10.2337/diacare.24.6.1069

9. Ali S, Stone MA, Peters JL, Davies MJ, Khunti K. The prevalence of co-morbid depression in adults with type 2 diabetes: a systematic review and meta-analysis. Diabet Med 2006;23:1165-73. https://doi.org/10.1111/j.1464-5491.2006.01943x

10. Meurs M, Roest AM, Wolffenbuttel BH, Stolk RP, de Jonge $P$, Rosmalen JG. Association of depressive and anxiety disorders with diagnosed versus undiagnosed diabetes: An epidemiological study of 90,686 participants. Psychosom Med 2016;78:233-41.

https://dx.doi.org, 10.1097, PSY0000000000000255

11. Kivimäki M, Tabák AG, Lawlor DB, Batty GD, Singh-Manoux $A$, Jokela $M$, et al. Antidepressant use before and after the diagnosis of type 2 diabetes: a longitudinal modeling study. Diabetes Care 2010;33:1471-6. https://doi.org/10.2337/dc09-2359

12. Rotella F, Mannucci E. Diabetes mellitus as a risk factor for depression. A meta-analysis of longitudinal studies. Diabetes Res Clin Pract 2013;99:98-104. https://doi.org/10.1016/j.diabres.2012.11.022

13. Khaledi M, Haghighatdoost F, Feizi A, Aminorroaya A. The prevalence of comorbid depression in patients with type 2 diabetes: an updated systematic review and meta-analysis on huge number of observational studies. Acta Diabetol 2019;56:631-50. https://doi.org/10.1007/s00592-019-01295-9

14. Degmecić D, Bacun T, Kovac V, Mioc J, Horvat J, Vcev A. Depression, anxiety and cognitive dysfunction in patients with type 2 diabetes mellitus - a study of adult patients with type 2 diabetes mellitus in Osijek, Croatia. Coll Antropol 2014;38:711-6. Available from: https://pdfs.semanticscholar.org/82a2/96eddeac3d0e1d281d48e2afa3eaOae ef60d.pdf (Letöltés ideje: 2019.12.10.)

15. Foran E, Hannigan A, Glynn L. Prevalence of depression in patients with type 2 diabetes mellitus in Irish primary care and the impact of depression on the control of diabetes. Ir J Med Sci 2015:184:319-22. https://doi.org/10.1007/s11845-014-1110-7.

16. Gorska-Ciebiada M, Saryusz-Wolska M, Ciebiada M, Loba J. Mild cognitive impairment and depressive symptoms in elderly patients with diabetes: Prevalence, risk factors, and comorbidity. J Diabetes Res 2014;2014:179648. https://doi.org/10.1155/2014/179648.

17. Indelicato L, Dauriz M, Santi L, Bonora F, Negri C, Cacciatori $V$, et al. Psychological distress, self-efficacy and glycemic control in type 2 diabetes. Nutr Metab Cardiovasc Dis 2017;27:300-6. https://doi.org/10.1016/j.numecd.2017.01.006

18. Jacob L, Kostev K. Prevalence of depression in type 2 diabetes patients in German primary care practices. J Diabetes Complications 2016;30:432-7.

https://doi.org/10.1016/j.jdiacomp.2015.12.013
19. Majdan M, Krajcovicova L, Pekarcikova J, Chereches $R$ $O^{\prime}$ Mullane $M$. Predictors of depression symptoms in patients with diabetes in Slovakia. Int J Psychiatry Med 2012;44:351-66 https://doi.org/10.2190/PM.44.4.e

20. Mikaliūkštienè A, Žagminas K, Juozulynas A, Narkauskaitè L Salyga J, Jankauskiene $K$, et al. Prevalence and determinants of anxiety and depression symptoms in patients with type 2 diabetes in Lithuania. Med Sci Monit 2014; 20:182-90. https://doi.org/10.12659/MSM.890019.

21. Mocan AŞ, lancu SŞ, Băban AS. Association of cognitiveemotional regulation strategies to depressive symptoms in type 2 diabetes patients. Rom J Intern Med 2018;56:34-40. https://doi.org/10.1515/rjim-2017-0037

22. Nefs $G$, Hendrieckx $C$, Reddy P, Browne IL, Bot M, Dixon J, et al. Comorbid elevated symptoms of anxiety and depression in adults with type 1 or type 2 diabetes: Results from the International Diabetes MILES Study. J Diabetes Complications 2019;33:523-9. https://doi.org/10.1016/j.jdiacomp.2019.04.013

23. Nowakowska M, Zghebi SS, Ashcroft DM, Buchan I, ChewGraham $C$, Holt T, et al. The comorbidity burden of type 2 diabetes mellitus: patterns, clusters and predictions from a large English primary care cohort. BMC Med 2019;17:145. https://doi.org/10.1186/s12916-019-1373-y

24. Pouwer F Geelhoed-Duijvestijn PH, Tack CJ, Bazelmans E Beekman AJ, Heine RJ, et al. Prevalence of comorbid depression is high in out-patients with Type 1 or Type 2 diabetes mellitus. Results from three out-patient clinics in the Netherlands. Diabet Med 2010;27:217-24. https://doi.org/10.1111/j.1464-5491.2009.02903.x

25. Salinero-Fort MA, Gómez-Campelo P, San Andrés-Rebollo FJ, Cárdenas-Valladolid J, Abánades-Herranz JC, Carrillo de Santa Pau E, et al. Prevalence of depression in patients with type 2 diabetes mellitus in Spain (the DIADEMA Study): results from the MADIABETES cohort. BMJ Open 2018;8:e020768. https://doi.org/10.1136/bmiopen-2017-020768

26. Sotiropoulos A, Papazafiropoulou A, Apostolou O, Kokolaki A, Gikas A, Pappas S. Prevalence of depressive symptoms among non insulin treated Greek type 2 diabetic subjects. BMC Res Notes 2008;1:101 https://doi.org/10.1186/1756-0500-1-101

27. Tabák AG, Akbaraly TN, Batty GD, Kivimäki M. Depression and type 2 diabetes: a causal association? Lancet Diabetes Endocrinol 2014;2:236-45. https://doi.org/10.1016/S2213-8587(13)70139-6

28. Hargittay Cs, Márkus B, Vörös K, Tabák GyÁ. A diabetes és a depresszió együttes előfordulása, lehetséges kétirányú kapcsolata és szúrésük jelentôsége. Orv Hetil 2019;160: 807-14. https://doi.org/10.1556/650.2019.31400

29. Rihmer Z, Purebl Gy, Faludi G, Halmy L. Az elhízás és depresszió kapcsolatai. Neuro-Psychopharmacol Hung 2008;10:183-9. Available from: https://epa.niif.hu/02400/ 02454/00031/pdf/EPA02454_neurohun_2008_183-189.pdf (Letöltés ideje: 2020.02.04.)

30. Prescribing and Medicines Team, NHS (National Health Service) Digital. Prescriptions Dispensed in the Commu nity England 2006 to 2016. Available from: https://files. digital.nhs.uk/publication/s/o/pres-disp-com-eng-200616-rep.pdf

31. Pratt LA, Brody DJ, Gu Q. Antidepressant Use Among Persons Aged 12 and Over: United States, 2011-2014. National Center for Health Statistics Data Brief 2017; No. 283. Available from: https://www.cdc.gov/nchs/data/ databriefs/db283.pdf (Letöltés ideje: 2020.01.11.)

32. Serretti A, Mandelli L. Antidepressants and body weight: a comprehensive review and meta-analysis. J Clin Psychiatry 2010;71:1259-72. https://doi.org/10.4088/JCP.09r05346blu

33. Rachdi C, Damak R, Fekih Romdhane F, Ouertani $H$, Cheour M. Impact of sertraline on weight, waist circumference and glycemic control: A prospective clinical trial on depressive diabetic type 2 patients. Prim Care Diabetes 2019;13:57-62. https://doi.org/10.1016/j.pcd.2018.09.003

34. Lustman PJ, Clouse RE, Nix BD, Freedland KE, Rubin EH, McGill JB, et al. Sertraline for prevention of depression recurrence in diabetes mellitus: a randomized, double- 
blind, placebo-controlled trial. Arch Gen Psychiatry 2006;63:521-9. https://doi.org/10.1001/archpsyc.63.5.521

35. McIntyre RS, Soczynska JK, Konarski IZ, Kennedy SH. The effect of antidepressants on glucose homeostasis and insulin sensitivity: synthesis and mechanisms. Expert Opin Drug Saf 2006:5:157-68. https://doi.org/10.1517/14740338.5.1.157

36. Ye Z, Chen L, Yang Z, Li Q, Huang Y, He M, et al. Metabolic effects of fluoxetine in adults with type 2 diabetes mellitus: A meta-analysis of randomized placebo-controlled trials. PLoS ONE 2011;6:e21551. https://doi.org/10.1371/journal.pone.0021551

37. Fava M. Weight gain and antidepressants. J Clin Psychiatry 2000;61:37-41. Available from: https://www.psychiatrist. com/jcp/article/pages/2000/v61s11/v61s1106.aspx (Letöltés ideje: 2020.01.10.)

38. Gilon P, Henquin JC. Mechanisms and physiological significance of the cholinergic control of pancreatic beta-cell function. Endocr Rev 2001:22:565-604. https://doi.org/10.1210/edrv.22.5.0440

39. Goodnick PI, Henry JH, Buki VM. Treatment of depression in patients with diabetes mellitus. J Clin Psychiatry 1995; 56:128-36. Available from: https://psycnet.apa.org/record/ 1995-41518-001 (Letöltés ideje: 2020.01.10.)

40. Barnard K, Peveler RC, Holt RI. Antidepressant medication as a risk factor for type 2 diabetes and impaired glucose regulation. Diabetes Care 2013;36:3337-45. https://doi.org/10.2337/dc13-0560

41. Goldstein DJ, Lu Y, Detke MJ, Lee TC, lyengar S. Duloxetine vs. placebo in patients with painful diabetic neuropathy. Pain 2005;116:109-18. https://doi.org/10.1016/j.pain.2005.03.029

42. Hardy $T$, Sachson $R$, Shen S, Armbruster M, Boulton AJ. Does treatment with duloxetine for neuropathic pain impact glycemic control? Diabetes Care 2007;30:21-6. https://doi.org/10.2337/dc06-0947

43. Hasnain M, Vieweg $W V$, Hollett $B$. Weight gain and glucose dysregulation with second-generation antipsychotics and antidepressants: a review for primary care physicians. Postgrad Med 2012;124:154-67. https://doi.org/10.3810/pgm.2012.07.2577

44. Song HR, Woo YS, Wang HR, Shim IH, Jun TY, Bahk WM. Does mirtazapine interfere with naturalistic diabetes treatment? J Clin Psychopharmacol 2014;34:588-94. https://doi.org/10.1097/ICP.0000000000000183

45. Sherman MM, Ungureanu S, Rey JA. Naltrexone/Bupropion ER (Contrave): Newly approved treatment option for chronic weight management in obese adults. P T 2016:41: 164-72. Available from: https://www.ncbi.n/m.nih.gov/ pmc/articles/PMC4771085/\#b7-ptj4103164 (Letöltés ideje: 2020.02.29.

46. European Medicines Agency. Mysimba. Available from https://www.ema.europa.eu/en/medicines/human/EPAR/m ysimba (Letöltés ideje: 2020.02.29.)

47. Sayuk GS, Gott BM, Nix BD, Lustman PJ. Improvement in sexual functioning in patients with type 2 diabetes and depression treated with bupropion. Diabetes Care 2011;34:332-4. https://doi.org/10.2337/dc10-1714
48. Lustman PJ, Williams MM, Sayuk GS, Nix BD, Clouse RE. Factors influencing glycemic control in type 2 diabetes during acute- and maintenance-phase treatment of major depressive disorder with bupropion. Diabetes Care 2007;30:459-66. https://doi.org/10.2337/dc06-1769

49. Mojtabai R. Antidepressant use and glycemic control. Psychopharmacology (Berl) 2013;227:467-77. https//doi.org/ 10.1007/s00213-013-2972-5

50. Kammer JR, Hosler AS, Leckman-Westin E, DiRienzo AG. Use of antidepressant medications not associated with $\mathrm{A}_{\text {, }}$ among individuals with diabetes in NHANES sample. Prim Care Diabetes 2016;10:360-8. https://doi.org/10.1016/j.pcd.2016.03.004

51. Kammer JR, Hosler AS, Leckman-Westin E, DiRienzo G, Osborn $C Y$. The association between antidepressant use and glycemic control in the Southern Community Cohort Study (SCCS). J Diabetes Complications 2016;30:242-7. https://doi.org/10.1016/j.jdiacomp.2015.10.017

52. Deuschle M. Effects of antidepressants on glucose metabolism and diabetes mellitus type 2 in adults. Curr Opin Psychiatry 2013;26:60-5. https://doi.org/10.1097/YCO.0b013e32835a4206.

53. Yoon JM, Cho EG, Lee HK, Park SM. Antidepressant use and diabetes mellitus risk: A meta-analysis. Korean J Fam Med 2013:34:228-40.

https://doi.org/10.4082/kjfm.2013.34.4.228

54. Salvi V, Grua I, Cerveri G, Mencacci C, Barone-Adesi F. The risk of new-onset diabetes in antidepressant users - A systematic review and meta-analysis. PLoS ONE 2017, 12:e0182088. https://doi.org/10.1371/journal.pone.0182088

55. Andersohn F, Schade R, Suissa S, Garbe E. Long-term use of antidepressants for depressive disorders and the risk of diabetes mellitus. Am J Psychiatry 2009;166:591-8. https://doi.org/10.1176/appi.ajp.2008.08071065

56. Kivimäki M, Hamer M, Batty GD, Geddes JR, Tabak AG, Pentti I, et al. Antidepressant medication use, weight gain and risk of type 2 diabetes: a population-based study. Diabetes Care 2010;33:2611-6. https://doi.org/10.2337/dc10-1187

57. Kivimäki M, Batty GD, Jokela M, Ebmeier KP, Vahtera Virtanen $M$, et al. Antidepressant medication use and risk of hyperglycemia and diabetes mellitus: a noncausal association? Biol Psychiatry 2011;70:978-84. https://doi.org/10.1016/j.biopsych.2011.07.008

58. Azevedo Da Silva M Dugravot A Balkau B, Roussel $R$ Fumeron F, Elbaz A. Antidepressant medication use and trajectories of fasting plasma glucose, glycated haemoglobin, b-cell function and insulin sensitivity: a 9-year longitudinal study of the D.E.S.I.R. cohort. Int J Epidemiol 2015,44:1927-40. https://doi.org/10.1093/ije/dyv153

59. Brieler JA, Lustman PJ, Scherrer JF, Salas J, Schneider FD. Antidepressant medication use and glycaemic control in co-morbid type 2 diabetes and depression. Fam Pract 2016;33:30-6. https://doi.org/10.1093/fampra/cmv100.r 